\title{
Religious tourism as a factor of tourism development in Greece: A case study of the monastery of St. Nektarios on Aegina
}

\author{
Dalibor Redžić ${ }^{*}$ \\ ${ }^{1}$ Singidunum University, Belgrade, Serbia
}

\begin{abstract}
The economic and political conditions prevailing both in Greece and around the world determine the overall development of all forms of tourism. The rapid development of specific forms of tourism, such as religious tourism, is gaining an increasing interest in the global tourism market. Religious tourism is one of the key factors for the development of the national economy, and it is also important because it represents the heritage for future generations of enormous cultural, ecological and social significance. Aegina island is characterized by rich natural and cultural resources that are recognizable for their authenticity and beauty, and as such are significant elements for the creation and development of specific forms of tourism. In a study of religious tourism in the St. Nektarios monastery on the island of Aegina, a study was conducted on the impact that religious tourism has on local development and the promotion of pilgrimage to the island of Aegina as a tourist destination of exceptional cultural and religious interest in the international tourist market. In addition, the paper emphasizes the importance of religious tourism as a specific form of tourism that contributes to the development of areas in which religious monuments are located.
\end{abstract}

Keywords: pilgrimage, religious tourism, St. Nektarios monastery, special forms of tourism, religious motives

JEL classification: L83, Z12

\section{Verski turizam kao faktor razvoja turizma u Grčkoj: Studija slučaja o manastiru svetog Nektarija na Egini}

Sažetak: Ekonomski i politički uslovi koji preovlađuju kako u Grčkoj tako i širom sveta određuju opšti razvoj svih oblika turizma. Ubrzan razvoj specifičnih oblika turizma poput verskog turizma dobija sve veći interes na globalnom turističkom tržištu. Verski turizam predstavlja jedan od ključnih faktora za razvoj nacionalne ekonomije, a značajan je po tome jer predstavlja nasleđe za buduće generacije od ogromnog kulturnog, ekološkog i društvenog značaja. Ostrvo Egina karakterišu bogati prirodni i kulturni resursi koji su prepoznatljivi po svojoj autentičnosti i lepoti, i kao takvi predstavljaju značajne elemente za stvaranje i razvoj specifičnih oblika turizma. U studiji slučaja o verskom turizmu u manastiru svetog Nektarija na ostrvu Egina, sprovedeno je istraživanje uticaja koji verski turizam ima na lokalni razvoj i promociju hodočašća na ostrvu Egina turističkoj destinaciji od izuzetnog kulturnog i verskog interesa na međunarodnom turističkom tržištu. Pored toga, u radu je stavljen akcenat na značaj verskog turizma као specifičnog oblika turizma koji doprinosi razvoju područja u kojima se nalaze verski spomenici. 
Ključne reči: hodočašće, verski turizam, manastir svetog Nektarija, posebni oblici turizma, verski motivi

JEL klasifikacija: L83, Z12

\section{Introduction}

Today, religious tourism is one of the fastest growing forms of tourism in the world. In recent years, Greece has seen a significant increase in foreign tourists visits to monasteries and churches in all parts of the country. Thus, religious tourism plays a very important role in the growth and development of tourism in Greece. It is estimated that over 300,000 Greek tourists visit religious sites annually in their country, and that $85 \%$ of the total number of international tourists to Greece visit some of the religious sites (Poulaki et al., 2015). Tourists and pilgrims from abroad who most often visit Greek monasteries mostly come from Eastern European and neighboring Balkan countries such as Serbia, Bulgaria and Romania (Skoultsos \& Vagionis, 2015).

The geographical position of Aegina island located in the Mediterranean basin and favorable climatic conditions provide ideal conditions for the development of religious tourism throughout the year. Aegina island is characterized by rich natural and cultural resources that are recognizable for their authenticity and beauty, and as such are significant elements for the creation and development of specific forms of tourism. The most important natural resources of Aegina are thick pine forests, seven endemic species of plants unique in Greece and thermal springs located near the town of Souvala in the northern part of the island. The most important cultural resources are the early antique settlement of Colona Hill, a temple dedicated to the ancient god Apollo, Venetian medieval fortress of Paleochora, and St. Cathernie and St. Nektarios monasteries. These resources as preserved cultural monuments testify to the history of Greek civilization and represent an inseparable part of the cultural and historical heritage of Greece. Compared to similar tourist destinations within the country visited by a large number of religious tourists and pilgrims, such as the islands of Patmos, Chios and Tinos, tourism on Aegina has not been developed to a satisfactory level, primarily due to the lack of tourism development and the improvement of tourism products and services. Religious and cultural wealth as an attractive resource in any tourist activity is a key potential for the development of religious tourism in Aegina island. This paper explores the importance of religious tourism on the Greek island of Aegina, where there are a large number of Orthodox monasteries and churches that are of utmost importance both for the Greeks and for all Orthodox believers in the world. In the conducted research, special emphasis was put on the contribution of religious tourism to the development of the local economy on the island of Aegina in order to identify the development potentials and opportunities for promoting the monastery of St. Nektarios as a destination of great religious interest.

\section{Literature review}

Today, tourism encompasses new cultural values that are focused on the sustainable development and preservation of the environment at the international level. This is related to numerous activities involved in tourism such as modern technology in transport, reservation systems, computer applications, business management, communication and marketing activities. According to Fernandes et al. (2012) religious tourism can be defined as a form of tourism whereby people of faith travel individually or in groups for reasons related to religion or spirituality in their quest for meaning. According to Durán-Sánchez et al. (2018) pilgrimage is a journey that comes from religious causes, externally to a holy site, and internally for spiritual purposes and internal understanding. Also, believers in sacred places 
seek communication with the Divine (Štefko et al, 2014). In addition to the classical pilgrimage, a modern version of pilgrimage is becoming more and more popular which, in addition to visiting the holy sites and religious monuments, includes a visit to the monuments of cultural and historical heritage and cultural pilgrimage (Griffin \& Raj, 2017).

Pilgrimage is mainly shaped by the influence of other factors that are currently dominating the market, such as economic, political, social and other factors. The issue that has been present in the scientific community for years is the difference between pilgrims and religious tourists (Polyxeni et al. 2009). The difference is present depending on the area in which a person travels (secular or religious), and according to the purpose of the journey, his/her wishes, behavior and needs are shaped (Van Nuenen \& Van Der Beek, 2016). AbadGalzacorta et al. (2016) considers that such a type of trip consists of two forms and only depends on the way and type of travel. The first form involves a religious feeling (pilgrim), and the second form involves a journey to acquire new knowledge that suits the profile of a religious tourist (Puscasu, 2015). Heather et al. (2014) considers that the journey of pilgrims and religious tourists includes two key dimensions in space and time. The main difference that separates the pilgrimage from other journeys is that time and space are unique, but at the same time it is a symbolic journey in which spiritual changes take place (Collins-Kreiner \& Wall, 2015). Bearing in mind that today there is vast literature on the topic of pilgrimage and tourism, there is lack of empirical work that deals with understanding the relationship between pilgrims and tourists, taking into account their similarities and differences (Stausberg, 2010). Pilgrimage and religious tourism are two different social phenomena that have touch points on religious elements (De Ascaniis \& Cantoni, 2017).

Thanks to its excellent geographical location, natural resources, developed infrastructure and preserved cultural and historical heritage, Greece has attracted many international tourists for years. The main reason why Greece attracts a great number of pilgrims and religious tourists from all over the world is its rich cultural and historical heritage, which besides monuments from the ancient period has a large number of Orthodox monasteries and churches that mostly originate from the period of Byzantine rule, numerous icons and books of priceless value, church relics, frescoes and more. The most important monuments of the cultural and historical heritage of Greece are the temple of Apollo Epicurius, Sanctuary of Delphi, Sanctuary of Asklepios, Mount Athos, medieval city of Rhodes, Meteora, Paleochristian and Byzantine monuments of Thessaloniki, archaeological site of Mystras, archaeological site of Olympia, archaeological site of Delos, archaeological sites of Mycenae and Tiryns, the monastery of Saint John Theologos and the cave of the Apocalypse in Patmos island (Visit Greece, 2019). Many monasteries and churches in Greece in addition to their great religious significance, are cultural monuments that are listed on the World Heritage List and under the protection of UNESCO. The UNESCO list includes 17 monuments of Greek cultural heritage, of which 7 are from the period of Byzantium and represent heritage of significant religious and cultural interest (UNESCO, 2018). The most significant monasteries from the Byzantine period on the UNESCO list of Greek cultural heritage visited by many pilgrims and tourists throughout the year are the monastery of Saint John Theologos and the cave of the Apocalypse in Patmos, the monasteries of Meteora, the monasteries of the Atos peninsula, church of St. Dimitrios in Thessaloniki and church of St. Spiridon in the city of Kerkyra (Religious Tourism in Greece, 2019). In a study of religious tourism at St. Nektarios Monastery research has been carried out on the contribution of religious tourism to local development and conditions for the promotion of religious tourism and the pilgrimage of the island of Aegina as a destination of immense religious and cultural importance in the international tourism market. 


\section{Research methodology}

The research includes the literature of numerous international authors, including tourist and religious journals used to identify changes in the international tourism market in terms of religious tourism, the website of the Tourism Organization of Greece, as well as the websites of travel agencies from Serbia that are active on the island of Aegina and which deal with the specific forms of tourism such as religious tourism and pilgrimage. In addition, in order to obtain relevant information on the research topic on the development of religious tourism in the monastery of St. Nektarios, as well as the significance of the island of Aegina as a place of special interest for pilgrims and religious tourists, a primary survey was conducted using questionnaires.

The primary research on market conditions was conducted at the level of visitors and travel agencies with the aim of assessing the tourist product of St. Nektarios monastery on the island of Aegina. Based on the questionnaire, the author analyzed the experience of visitors who visited St. Nektarios monastery, their suggestions for the improvement and development of new tourist products, as well as the opportunities for attracting new market segments. The responses of travel agencies that organize trips to the island of Aegina have also been analyzed to determine ways to improve the sales of tourist packages for travel agencies that specialize in specific forms of tourism such as religious tourism in order to improve tourism promotion and development both in the area of St. Nektarios monastery and on the island of Aegina. The results of the survey were supplemented by the collected data obtained from structured interviews. In order to obtain relevant responses, a structured questionnaire is designed based on a set of rules as to avoid hypothetical questions, obscure terms and expressions, questions that require answers about past events, and questions requiring the provision of personal data. In order to better formulate the questions, Likert Scale was used. The questionnaire consisted of 35 questions and it was divided into two parts. The first part of the questionnaire contained 15 questions related to the profile of the monastery visitors, while the other part contained 20 mixed questions related to the selection of St. Nektarios monastery as the ultimate destination. In total 160 questionnaires were distributed by e-mail and local distribution at the destination to tourists who first visited the St. Nektarios monastery and who are not permanent inhabitants of the island. The questionnaire for travel agencies consisted of three parts. The first part of the questionnaire contained 6 questions related to the profile of the travel agency, the second part contained 8 questions about the customer profile, and the third part contained 16 mixed questions related to the evaluation of the tourist destination. A total of 15 questionnaires were distributed via e-mail to travel agencies that organize tourist trips and pilgrimages on the island of Aegina. Structured interviews were conducted with hotel owners located in the city of Aegina. The conducted qualitative research using structured questioning aimed at identifying key factors that significantly influence the behavior of customers towards tourism products and services. A total of 12 structured interviews were conducted. Based on the conducted interviews, the answers received were captured in writing. The survey was conducted in the period from $1 \mathrm{st}$ August 2018 to 1st September 2018.

\section{Research results and discussion}

By analyzing the answers from the primary research, the following results were obtained. The visitors filled out a total of 117 questionnaires, travel agencies filled out 13 questionnaires, and a total of 12 complete interviews were conducted with hotel owners. 


\subsection{Visitor questionnaire results}

By analyzing the visitor's responses, we found that the main motive for their trip to Aegina island was pilgrimage (Figure 1).

Figure 1: The main motives of visitors for a trip to St. Nektarios monastery

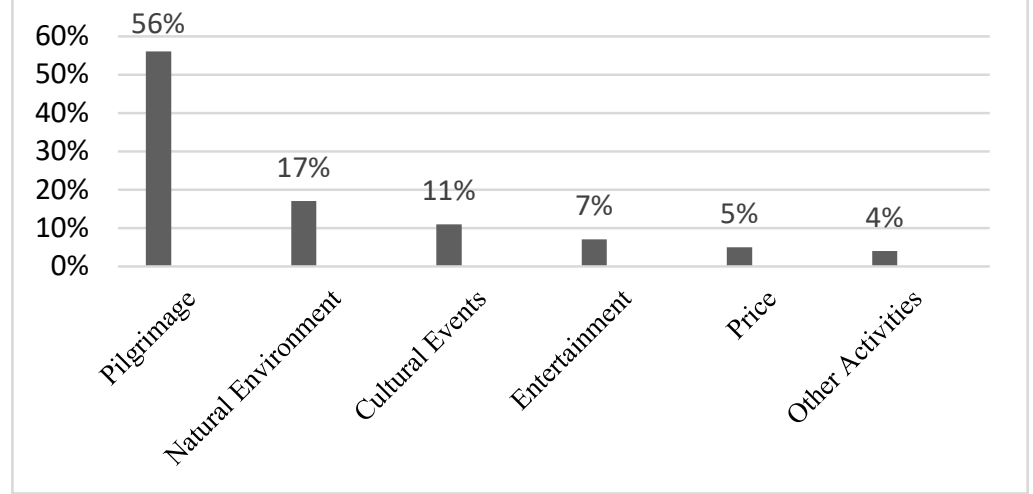

Source: Author

Most visitors who visited the St. Nektarios monastery stayed on the island of Aegina for a maximum of two days (Figure 2).

Figure 2: Average number of nights of stay

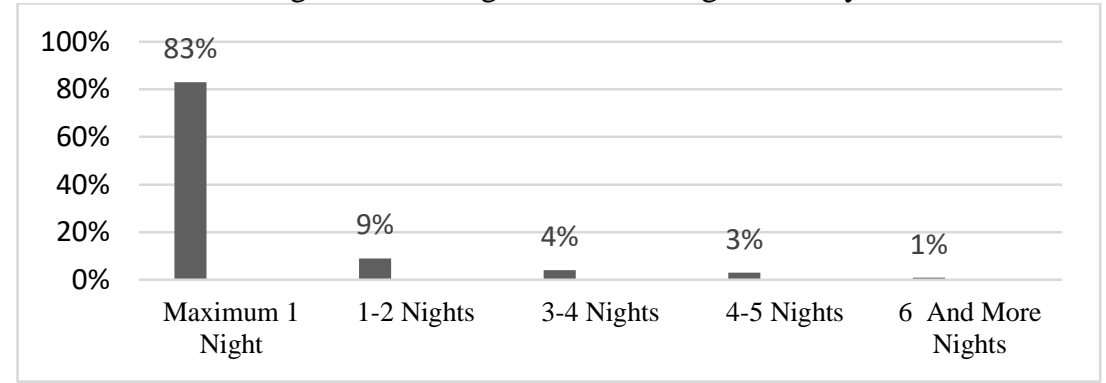

Source: Author

Infrastructure and access to religious monuments represent some of the weaknesses of the destination on whose development special attention must be paid to fully meet the needs and demands of visitors, and also promote the destination on the international tourist market (Figure 3).

Figure 3: Key weaknesses of the destination

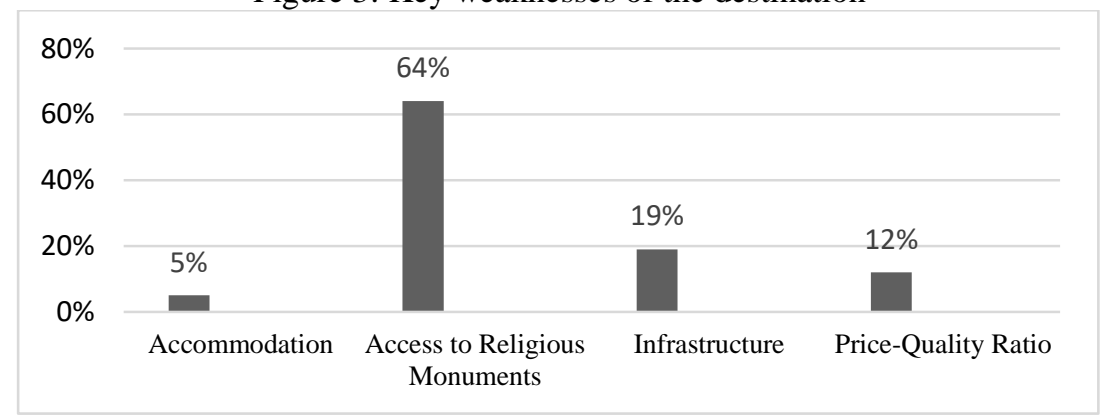

Source: Author 


\subsection{Results of travel agencies survey}

Travel agencies that participated in the research are agencies from Serbia that organize pilgrimage and tourist trips to the Greek island of Aegina. Travel agencies mainly organize trips to the island of Aegina in cooperation with the Serbian Orthodox Church, at the request of church parishes, numerous associations, institutions and individuals. Travel agencies organize trips to Aegina throughout the year, especially during great religious holidays such as Easter, Christmas and St. Nektarios day, because during that period there is great interest of pilgrims and religious tourists to travel to the destination.

Figure 4: Groups from Serbia, which most often travel to the monastery of St. Nectarios and the island of Aegina

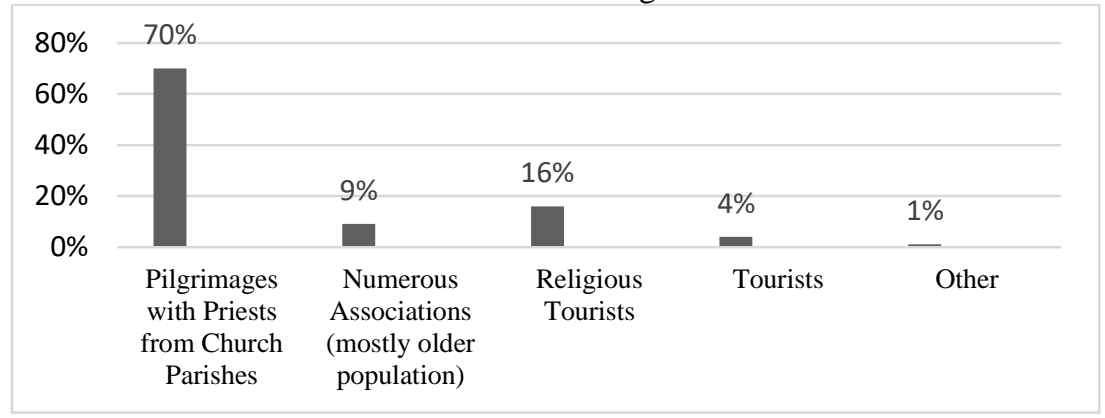

Source: Author

The largest percentage of travel agents agreed that tourists and pilgrims travel to St. Nektarios monastery throughout the year, which means that there is no specific time / season during the year when tourists and pilgrims travel and that their fluctuation is distributed throughout the year (Figure 5).

Figure 5: Period of visit of tourists and pilgrims to the destination

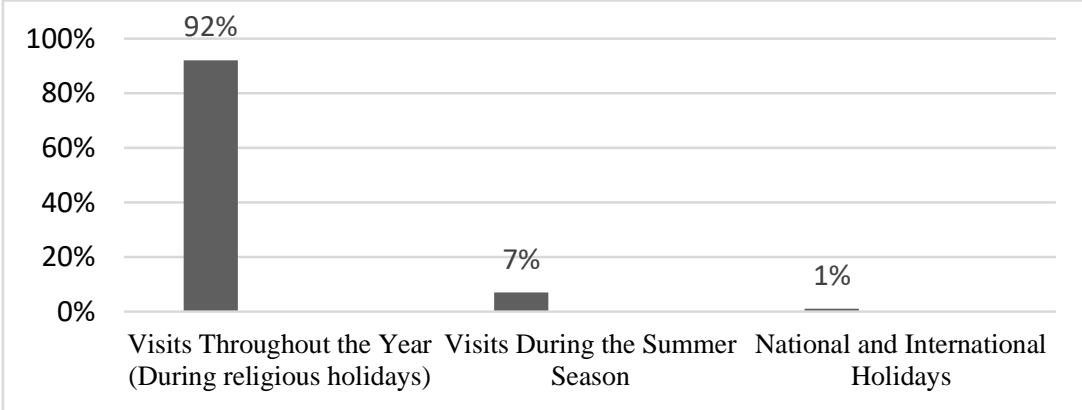

Source: Author

For travel agencies, the key potential for tourism development at the destination is the cultural and historical heritage, the preserved natural environment as well as the Mediterranean climate that creates the ideal conditions for visiting the destination throughout the year. Based on these factors, travel agencies plan to organize pilgrimage and tourist trips in the future on the island of Aegina, and some agencies plan to organize their tourist packages in combination with other specific forms of tourism at the destination (Figure 6). 
Figure 6: Elements that represent a key potential for tourism development at Aegina

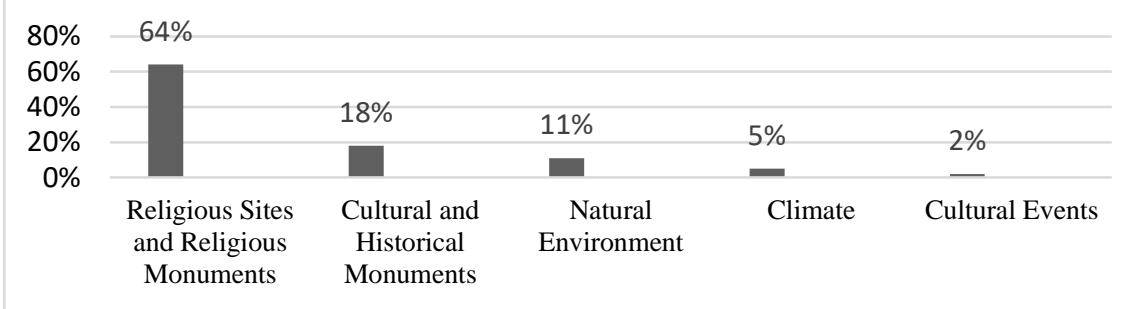

Source: Author

\subsection{Interview results}

By analyzing the answers received from the conducted interviews, we found that the highest percentage of respondents gave approximate answers to questions related to the average age of visitors, their education and their marital status. Accordingly, the average age of visitors is between 45 and 60 years old, more than half are married persons, the majority of visitors are women. The highest percentage of visitors is persons with either secondary or higher education and on the basis of income they belong to middle and upper middle class. Also, the largest number of elderly people prefers organized group trips by bus, while younger people travel most often with their own means of transport (Figure 7).

Figure 7: Visitor profile

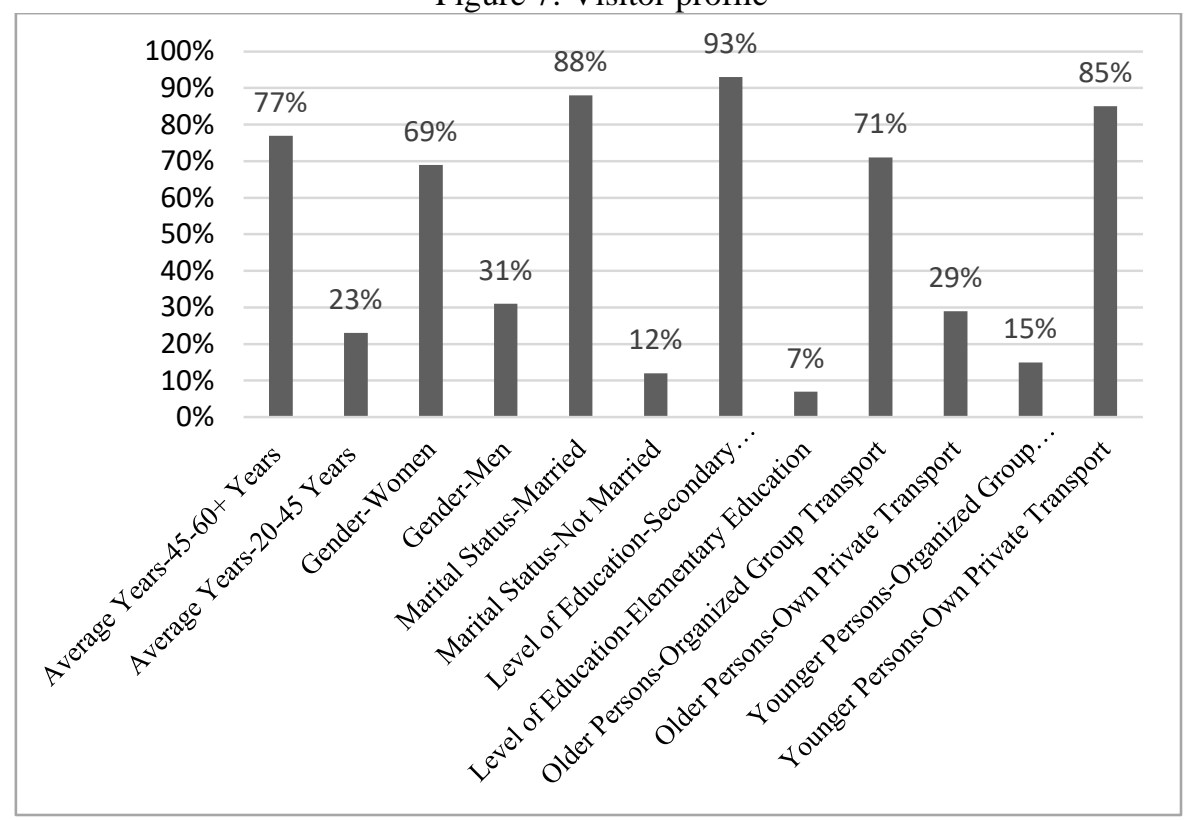

Source: Author

Visitors mostly come from Eastern European countries and stay on average from one to two nights, while domestic Greek tourists stay on average for three or more nights at the destination. Due to the small number of beds in monastery apartments, and also because of the small number of apartments in the place where the monastery is located, visitors most often stay in the town of Aegina where the largest number of accommodation facilities is located, such as apartments, hotels and hostels. At the destination, there are not many hotels with four and five stars that would attract tourists with special and high demands. Existing 
hotels where tourists most often stay make their efforts in order to fulfill the needs and requirements of guests based on the delivery of quality services. At the destination, there is no special tourist development which is especially reflected in the poor development of infrastructure whose reconstruction and development would have a significant impact on the improvement of the conditions for the development of tourism on the level of the entire destination. The coordination among stakeholders in tourism that is active at the destination is not at a satisfactory level, which is largely reflected in insufficient tourism development. Regarding local traffic and road network, there are some weaknesses that are reflected in the poor correlation between certain points at the destination and underdeveloped internal transport networks. Most respondents agree that the pilgrimage to the monastery of St. Nektarios can also be combined with visiting other places of religious interest to Aegina as well as monasteries in the wider area of the destination.

\subsection{Comparison of research findings}

The results of the conducted secondary research indicate that the tourist policies and strategies as well as the tourist planning at the tourist destination have not been elaborated in the best way. Responses gained by questionnaires that included visitors and travel agencies as well as interview responses largely coincide, in particular on questions related to travel motives, visitor profiles, ratings and elements that represent the potential as well as the disadvantages for the development of tourism at the destination. Also, the answers from questionnaires and interviews related to the development of religious tourism at the research destination obtained from travel agencies and hotel owners are approximately identical. In the conducted interview, the respondents pointed to the main disadvantages that adversely affect the development of tourism at the destination such as underdeveloped infrastructure, difficult access to tourist attractions, the absence of tourism policies and strategies, as well as poor coordination of local authorities with regard to tourism development, but respondents also expressed the need for tourism development.

\section{Conclusion}

In order to establish a balanced development of religious tourism in the research area, it is necessary to establish a framework of organized tourism policy based on the selection of key priorities for the development of religious tourism and with the adequate use of appropriate means of implementation. Converting comparative to a competitive advantage by respecting cultural identity and preserving cultural, historical and religious heritage should be the primary goal of religious tourism development. Also, the development of actions, promotion and promotion of the destination in the international tourist market as well as undertaking actions aimed at attracting the younger population of visitors through sending clear messages about religious sites and monuments at the destination plays an important role in the development of religious tourism, especially because of the multiculturality of society in a global context. Strategic approach to the area of the St. Nektarios monastery should include the participation of the state as well as undertaking joint activities in order to attract domestic and foreign investors in order to restore and build new infrastructure to make access to the area of the monastery much faster and safer. In addition, investment projects for the modernization of existing and construction of new hotels, improvement of accommodation quality, improvement of the quality of tourism products and services, implementation of training programs and education of employees on religious tourism, organization of events in the field of culture and religion are elements that play a significant role in the development of religious tourism on the island of Aegina. 


\section{Study limitations and future research}

The main constraint in conducting research was long-term access to visitors in collecting responses to fill in the questionnaire. As a limitation, we can also indicate the avoidance of visitors to participate in the research, citing numerous reasons for this, as well as their mistrust that has been overcome by explaining that it is an analytical research. In addition, as a limitation during the survey, we can also indicate the avoidance of a small number of hotel owners to participate in a structured interview, stating a number of reasons such as lack of free time, while the majority agreed with pleasure to participate in the research. Some travel agencies refused to take part in the survey, stating the overload of work as the main reason, but it was soon overcome in a telephone conversation where the purpose and subject of the study were explained. Future research should include a more precise identification of similarities and differences between religious tourists and pilgrims as well as a more comprehensive understanding of the relationship between them. doi:10.21427/D7KT5N

\section{References}

1. Abad-Galzacorta, M., Guereño-Omil, B., Makua-Biurrun, A., Santomà, R., \& Luis Iriberri, J. (2016). Pilgrimage as tourism experience: A preliminary approach to profiling pilgrims on the Ignatian Way. International Journal of Religious Tourism and Pilgrimage, 4(4), 48-66. https://doi.org/10.21427/D7KT5N

2. Collins-Kreiner, \& N., Wall, G. (2015). Tourism and religion: Spiritual journeys and their consequences. In S. Brunn (Ed.), The changing world religion map (pp. 689-707). Dordrecht, Netherlands: Springer.

3. De Ascaniis, S., \& Cantoni, L. (2017). Online visit opinions about attractions of the religious heritage: An argumentative approach. Church, Communication and Culture, 2(2), 179-202. http://doi.org/10.1080/23753234.2017.1350585

4. Durán-Sánchez, A., Álvarez-García, J., Del Rio Rama, M., \& Oliveira, C. (2018). Religious tourism and pilgrimage: Bibliometric overview. Religions Journal, 9(9), 115. https://doi.org/10.3390/re19090249

5. Fernandes, C., Pimenta, E., Gonçalves, F., \& Rachão, S. (2012). A new research approach for religious tourism: The case study of the Portuguese route to Santiago. International Journal of Tourism Policy, 4(2), 83-94. https://doi.org/10.1504/IJTP.2012.048996

6. Griffin, K., \& Raj, R. (2017). The importance of religious tourism and pilgrimage: Reflecting on definitions, motives and data. International Journal of Religious Tourism and Pilgrimage, 5(3), 1-9. https://doi.org/10.21427/D7242Z

7. Heather, W., Baker, S., \& Foxx, S. (2014). The therapeutic value of pilgrimage: A grounded theory study. Mental Health, Religion \& Culture, 17(8), 860-875. https://doi.org/10.1080/13674676.2014.936845

8. Polyxeni, M., Parthenis, S., Kontoudaki, A., \& Katsoula O. (2009). Religious tourism in Greece: The necessity to classify religious resources for their rational valorization. International Congress: Tourism, Religious \& Culture: Regional Tourism Development through Meaningful Experiences (pp. 465-480). Tricase, Italy: University of Mario Congredo.

9. Poulaki, P., Lagos, D., \& Balomenou, C. (2015). Religious Tourism in Greece and regional development: The case of Samos Island. Conference: 55th ERSA CONGRESS "World Renaissance: Changing Roles for People and Places" (pp. 1-25). Lisbon, Portugal: Lisboa School of Economics and Managment.

10. Puscasu, V. (2015). Religious tourism or pilgrimage. European Journal of Science and Theology, 11(3), 131-142. 
11. Religious Tourism in Greece. Retrieved May 2, 2019 from https://www.pilgrimtours.gr/mediaupload/various/pdf/religioustourismingreece.pdf

12. Skoultsos, S., \& Vagionis, N. (2015). Cultural and religious tourism as parts of Greek tourism product. 1st International Conference on Experiential Tourism (pp. 1-9). Santorini, Greece: Heliotopos Conferences.

13. Stausberg, M. (2010). Religion and tourism: Crossroads, destinations and encounters. London: Routledge.

14. Štefko, R., Királ'ováb, A., \& Mudrík, M. (2014). Strategic marketing communication in pilgrimage tourism. International Conference on Strategic Innovative Marketing (pp. 423-430). Madrid, Spain: Procedia - Social and Behavioral Sciences.

15. UNESCO, World Heritage sites in Greece. Retrieved February 26, 2019 from https://whc.unesco.org/en/statesparties/gr

16. Van Nuenen, T., \& Van Der Beek, S. (2016). Pilgrim or tourist? Modelling two types of Travel Bloggers. Heidelberg Journal of Religions on the Internet, 11(1), 138-163. https://doi.org/10.17885/heiup.rel.2016.0.23631

17. Visit Greece, Greece as a World Heritage site. Retrieved May 2, 2019 from http://www.visitgreece.gr/en/culture/world_heritage_sites

Received: 9 April 2019; Sent for revision: 4 May 2019; Accepted: 27 May 2019 